\title{
Re-forming property to address eco-social fragmentation and rift
}

\author{
Margaret Davies* \\ Matthew Flinders Distinguished Professor, Flinders University
}

Two concepts that bridge the nature-human divide may help to diagnose and address some of the present and future problems of eco-social change in a legal context. 'Fragmentation' refers to loss and degradation of the habitat of nonhuman life. It is also a useful concept for understanding the fracturing of the material conditions for human life in a modern globalised world. The notion of 'metabolic rift', derived from Marx by John Bellamy Foster, refers to a break in the human-nonhuman circulation of natural materials, brought on by industrial agriculture and urbanisation. These related ideas provide a frame for exploring the connections between social and environmental justice and the role played by legal forms such as private property. In keeping with the imperative to re-form legal concepts to account for eco-social existence, the article presents a view of property as human and nonhuman habitat. This approach aims to use law to help recreate the conditions for the constructive inter-dependence of social and environmental goods.

Keywords: property, metabolic rift, fragmentation, habitat, environmental justice

\section{INTRODUCTION}

Across all scholarly disciplines and all fields of human activity commentators and activists are now finding ways to reintegrate what have often, in the scholarly traditions of the modernist and postmodernist West, been understood as separate natural and human spaces. The trend towards - and indeed necessity of - starting with the embeddedness of the human species in an extended physical reality is equally beginning to drive legal scholarship. Western ideas of law throughout the modern era have been structured by the mythologies of human separateness from nature and by

* Orcid.org/0000-0003-1546-7204. This research has been funded by the Australian Research Council DP190101373 'Property as Habitat'. Many of the ideas developed in this paper are the product of collaborative thinking and I am indebted to my co-investigators on the project, Lee Godden and Nicole Graham, for their individual and joint input. See eg, Nicole Graham 'Dephysicalized Property and Shadow Lands' in Robyn Bartel and Jennifer Carter (eds), Handbook on Space, Place, and Law (Edward Elgar, Cheltenham UK 2021); Lee Godden 'Legal Geography - Place, Time, Law and Method: The Spatial and Archival in Connection to Country' in Tayanah O'Donnell, Daniel Robinson, and Josephine Gillespie (eds), Legal Geography: Perspectives and Methods (Routledge, Abingdon 2020). Earlier forms of this paper were delivered as the Annual Lecture in Law and Social Justice, Leeds University October 2019 and a plenary lecture at the Law and Society of Australia and New Zealand, December 2019, Southern Cross University. I would like to thank the audiences on these occasions for their helpful questions and comments. Finally I'd like to thank the anonymous referees and the Editor-in-Chief Anna Grear for their many comments and, in particular, for helpful suggestions about strengthening the argument. 
universalism - mythologies relying on abstraction from everyday materiality. These mythologies stand in sharp contrast to the older place-emergent legal narratives of Indigenous peoples, which are now providing inspiration and some guidance for mainstream legal scholarship. One symptom of the turn towards ecological materiality is the emergence of new terms that bridge the traditional divisions typical of Western thought: these terms include natureculture, socionature, bioculture, eco-society, biolegality, and eco-legality.

The project of bending law towards a less abstract and more materially integrated understanding of the world is neither simple nor short-term. What is needed is a collective and widespread regeneration of legal concepts. The critical legal project of the twenty-first century and beyond will involve both deployment of the techniques and insights of past critique as well as an ontological rebuilding towards what might for the moment be characterized as posthuman law or as eco-legality. ${ }^{1}$ This project has commenced and I believe it will continue to strengthen over the coming decades in response to a new consciousness of planetary and ecological imperatives. ${ }^{2}$ It is an extensive undertaking involving nothing less than the complete reconceptualization of fundamental legal concepts for an eco-social future.

In this article, I consider the relationship between eco-social materiality and the idea of property as it has been developed and practised in the capitalist world. In Western economies, property is (as was once said of liberalism ${ }^{3}$ ) the 'air we breathe' and it is therefore especially important to understand its role in the ecological destruction we are currently witnessing. Re-forming property as an idea, a practice, and an institution in a way that is materially responsive and (for land) situated in space $^{4}$ is one of the most significant adjustments required for a more resilient and sustainable social-ecological future. This is no simple task, as the thought and practice of property engages an entire ontological landscape for which subjects are separate from objects and human individuals control 'external' things. ${ }^{5}$ In Australia, where I live and work, this colonial and Eurocentric ontology is in constant conflict with the

1. These terms are placeholders, signifying a transition away from twentieth-century abstract and separate notions of law, but not yet entirely matched to whatever is to come.

2. See, for instance, Anna Grear, 'The Vulnerable Living Order: Human Rights and the Environment in a Critical and Philosophical Perspective' (2011) 2(1) Journal of Human Rights and the Environment 23-44; Anna Grear, 'Deconstructing Anthropos: A Critical Legal Reflection on "Anthropocentric" Law and Anthropocene "Humanity" (2015) 26 Law and Critique 225-229; Andreas Philippopoulos-Mihalopoulos, ““...the Sound of a Breaking String”: Critical Environmental Law and Ontological Vulnerability' (2011) 2(1) Journal of Human Rights and the Environment 5-22; Astridis Niemanis, 'Alongside the Right to Water, a Posthumanist Feminist Imaginary' (2014) 5 Journal of Human Rights and the Environment 5-24; Daniel Matthews, 'Law and Aesthetics in the Anthropocene: From the Rights of Nature to the Aesthesis of Obligations' (2019) Law, Culture, and the Humanities (online), DOI: 10.1177/ 1743872119871830 .

3. Anthony Arblaster, The Rise and Decline of Western Liberalism (Basil Blackwell, Oxford 1984) 6 .

4. Nicole Graham, Lawscape: Property, Environment, Law (Routledge, Abingdon 2011).

5. Bradley Bryan, 'Property as Ontology: On Aboriginal and English Understandings of Ownership' (2000) 13 Canadian Journal of Law and Jurisprudence 3-31; on the issue of plural ontologies see Maria Lugones, 'Playfulness, "World-Traveling", and Loving Perception' (1987) 2 Hypatia 3-19; Annemarie Mol, 'Ontological Politics: A Word and Some Questions' (1999) 47 (supplement to issue 1) Sociological Review 74-89; Marisol de la Cadena and Mario Blaser (eds), A World of Many Worlds (Duke University Press, Durham 2018). 
much older ontologies of Aboriginal peoples. Similar conflicts are repeated throughout the colonized world, taking many localized forms. Two related imperatives for the legal theory of Australia, of the Anglosphere, and more generally of the capitalist West, are first to develop an openness to alternative ontologies and second to specifically cultivate the theoretical resources of European thought and its derivatives so that material interconnection is understood to be fundamental to existence rather than a secondary process performed by entities that are naturally distinct. This article is directed at the furtherance of the second of these imperatives. It consolidates and to some extent reframes extensive analysis already conducted in the scholarly literature and argues for a conception of property that recognizes the co-emergence of subject and object in complex and ecologically open locations.

Before turning to consider property, however, some groundwork is needed. The first part of the article briefly outlines transitions in politics and consciousness concerning the relationship between human society and the ecological sphere: in essence this shift consists of a move from a view of society as human to an integrated eco-social consciousness. In the second and third parts of the article I use two images - fragmentation and rift - as explanatory devices for the multiple axes of material disintegration that have led the capitalist West to this historical moment. As I will explain, 'fragmentation' and 'rift' are composite terms: they are concepts that describe ongoing material-historical ruptures in ecological processes. To be fragmented and riven from environmental conditions are also onto-epistemological modes of being human that are produced by Euro-colonial cultures. The language of fragmentation and rift is intended, therefore, to capture processes across intersecting biological, physical, and cultural planes, and therefore to communicate the need to imagine remedies and reforms that are practical co-becomings of the human and nonhuman. ${ }^{6}$ In the final two parts, I turn to property and habitat. As presently imagined and practised, the institution of private property is strongly implicated in - we might even say responsible for - ecocide, meaning that property's justification needs to be questioned and its form radically changed. ${ }^{7} \mathrm{We}$ need to reimagine it as a relational form that that could improve rather than destroy the biosocial conditions for life.

\subsection{From society to eco-society}

In much mainstream and politically neoliberal commentary, environmental protection continues to be seen as an impediment to economic development and improvement,

6. See generally, eg, Donna Haraway, The Companion Species Manifesto: Dogs, People, and Significant Otherness (Prickly Paradigm Press, Chicago 2003); Bawaka Country et al., 'Caring as Country: Towards an Ontology of Co-Becoming in Natural Resource Management' (2013) 54(2) Asia-Pacific Viewpoint 185-97; Vito de Lucia, 'Re-embodying Law: Transversal Ecology and the Commons' in Ruth Thomas-Pellicer, Vito De Lucia and Sian Sullivan (eds), Contributions to Law, Philosophy and Ecology: Exploring Re-Embodiments (Routledge, Abingdon 2016).

7. On the justifications for property see Margaret Davies, 'Can Property be Justified in an Entangled World?' (2020) 17(7) Globalizations 1104-17; on change to the form of private property see, among many others, Nin Tomas, 'Maori Concepts of Rangatiratanga, Kaitiakitanga, the Environment and Property Rights' in David Grinlinton and Prue Taylor (eds), Property Rights and Sustainability: The Evolution of Property Rights to Meet Ecological Challenges (Martinus Nijhoff, Leiden 2011); William Lucy and Catherine Mitchell, 'Replacing Private Property: The Case for Stewardship' (1996) 55 Cambridge Law Journal 566-600. 
and therefore as an impediment to social well-being. Through this lens, environmental harms are framed as being necessary for the social good, which in turn is seen to rely on employment and economic growth. ${ }^{8}$ The extractive narrative that dominated the twentieth century erases or downplays the long-lasting harms of environmental damage that accrue to both human and nonhuman communities. By contrast, in the twenty-first century, environment-related harms are now more widely understood as harming particular human communities, humanity at large (albeit unevenly), and planetary ecosystems.

The distributional impacts of harm to nature can be and are increasingly understood to be both intra-human and ecological. ${ }^{9}$ It is widely accepted that, within human society, it is marginalized and vulnerable communities that suffer first and most severely from environmental injustices. ${ }^{10}$ There are many shocking examples of industry externalizing its costs to the detriment both of ecosystems and marginalized human communities. ${ }^{11}$ Moreover, much environmental injustice is not accidental but rather deliberate: highly polluting industries are co-located with poor communities, who might also be forced to follow such industries for work; national and global 'sacrifice zones' are created so that environmental harms such as open-cut mines and waste dumps are concentrated in specific locations, ${ }^{12}$ relatively wealthy industrialized countries export waste to less developed parts of the world. ${ }^{13}$ There also exist other seemingly endless, multiply situated, ${ }^{14}$ eco-social harms that are not necessarily directly intended but are rather the result of policy failures.

8. Critiques of neoliberal fundamentalism are now widespread: see, for instance, Jonathan D Ostry, Prakash Lougani, and Davide Furceri, 'Neoliberalism: Oversold?' (2016) 53(2) Finance and Development: A Quarterly Magazine of the IMF 38-41; Chystia Freeland, Plutocrats: The Rise of the New Global Super-rich and the Fall of Everyone Else (Penguin Books, London and New York 2013).

9. Christie Parris et al., 'Justice for All? Factors Affecting Perceptions of Environmental and Ecological Injustice' (2014) 27 Social Justice Research 67-98.

10. As I write, historically unprecedented bushfires are destroying large areas of the Australian landscape. The intensity and extent of the bushfires are much worse because of human-induced climate change. In some senses, it appears that the relatively wealthy communities of Australia are at the forefront of the climate crisis. However, it must be noted that widespread devastation is less visible in poorer areas of the world, that relative wealth brings a level of resilience to crisis, and that indeed such wealth has come from full participation in the environmentally exploitative practices of industrialism and industrial agriculture.

11. Several thousand high-profile examples are documented in the Environmental Justice Atlas (ejatlas.org) but this is presumably a small fraction of the environmental injustices worldwide. See also Ryan Holifield, Jayajit Chakraborty, and Gordon Walker (eds), The Routledge Handbook of Environmental Justice (Routledge, Abingdon 2018).

12. Julia Fox, 'Mountaintop Removal in West Virginia: An Environmental Sacrifice Zone' (1999) 12(2) Organization and Environment 163-83; Drew Cottle, 'Land, Life, and Labour in the Sacrifice Zone: The Socio-Economic Dynamics of Open-Cut Coal Mining in the Upper Hunter Valley, New South Wales' (2013) 22(3) Rural Society 208-16; Neera Singh, 'Environmental Justice, Degrowth, and Post-capitalist Futures' (2019) 163 Ecological Economics 138-42.

13. Silpa Kaza, Lisa Yao, Perinez Bhada-Tata, and Frank van Woerden, What a Waste 2.0: A Global Snapshot of Solid Waste Management to 2050 (World Bank Urban Development Series, 2018); Val Plumwood, 'Shadow Places and the Politics of Dwelling' (2008) 44 Australian Humanities Review 139-50.

14. Gordon Walker, 'Beyond Distribution and Proximity: Exploring the Multiple Spatialities of Environmental Injustice' (2009) 41(4) Antipode 614-36. 
For instance, poorly mitigated climate change underpins disasters that are more frequent and more intense because of global warming, whether these are bushfires or inundations, storms or droughts, resulting in numerous impacts on health, food, water, infrastructure, and economies. ${ }^{15}$ Some environmental harms affect people indiscriminately but it is still clear that the poorest populations are also the most vulnerable to and the least resilient in the face of environmental destruction. ${ }^{16}$ The terms 'environmental racism', 'environmental injustice', and 'toxic colonialism' were coined decades ago to describe these global transfers of environmental damage from the wealthy to the poor, ${ }^{17}$ transfers that are one form of continuing racial and colonial politics responsible for the devastation both of peoples and ecological systems. That those who are the least responsible for ecosystem collapse and climate change suffer the most means that environmental harms are legible as a form of social injustice aligned with inequities in procedure, distribution, and recognition: ${ }^{18}$ environmental harm both intensifies injustices that already exist in the distribution of resources and creates entirely new forms of injustice.

Environmental destruction can therefore be understood as having a direct, but external, relationship to the material conditions of human social life. In the extractive narratives it is regarded as necessary for the advancement of society, while in certain environmental justice narratives it is understood as causing harm to specific human communities. Both the discursive framing of environmental issues through paradigms of, on the one hand, economic growth and, on the other, social justice, discrimination, and inequality can easily separate nature from human society. The environment - the entire nonhuman sphere - is thus seen as something other than humanity: human society shapes and acts upon the environment and has the capacity to continue in its destructive ways or to desist. This framing that perceives effects on human society as qualitatively different from harms to the nonhuman sphere draws upon the default framework of Western and colonial culture, the one which many of us trained in this tradition frequently revert to in trying to understand contemporary problems. Alternative worldviews that do not so sharply divide the human from the nonhuman remain common, however, outside the traditions of Western Europe, particularly among

15. Camilo Mora et al., 'Broad Threat to Humanity from Cumulative Climate Hazards Intensified by Greenhouse Gas Emissions' (2018) 8 Nature Climate Change 1062-71.

16. In the midst of the Australian bushfire crisis one commentator wrote 'In a matter of weeks Canberra - a city known for its crisp sunny skies and eucalyptus smell - has shown us how every aspect of climate change disproportionately impacts those who have the least social and economic resources. The city has air inequity, where those with high incomes can purchase thousand dollar air purifiers, while those who do not sit in their homes marinating in particulate counts that are known to be beyond hazardous.' Gemma Carey, 'Being Pregnant in a Climate Emergency was an Existential Challenge. Miscarriage has Brought a New Grief', Guardian Australia (10 January 2020).

17. Robert Bullard, Dumping in Dixie: Race, Class, and Environmental Quality (Westview Press, Boulder CO 1990); Robert Bullard (ed), Confronting Environmental Racism Voices from the Grassroots (South End Press, Cambridge, MA 1993); Paul Mohai and Bunyan Bryant, 'Environmental Injustice: Weighing Race and Class as Factors in the Distribution of Environmental Hazards' (1992) 63 University of Colorado Law Review 921-32; Susan Cutter, 'Race, Class, and Environmental Justice' (1995) 19(1) Progress in Human Geography 111-22; Robert Bullard, Environment and Morality: Confronting Environmental Racism in the United States (UN Research Institute for Social Development 2004); Susan Buckingham and Rakibe Kulcur, 'Gendered Geographies of Environmental Justice' (2009) 41(4) Antipode 659-83.

18. Gordon Walker, 'Beyond Distribution and Proximity: Exploring the Multiple Spatialities of Environmental Injustice’ (2009) 41(4) Antipode 614-36. 
Indigenous peoples ${ }^{19}$ whose thoroughly relational ontology perceives the emergence of living entities in their ecological and continuously lived connections. ${ }^{20}$ Yet, throughout Western history, there have also been counter-narratives to the view that human society is above nature. The separation of human from nonhuman that has led to a human-centred or anthropocentric default position is now widely challenged in order to account for several critical facts: first, humans are physical beings, not abstract individuals; second, human life has emerged, and continues to emerge, from the biosphere and is entirely entwined with it (indeed the production of life forms occurs as energetic-material flows through a dense multi-scalar network, from atoms to organisms, to groups) $;^{21}$ and third, like all life, humans are wholly dependent on the physical world and in particular the soil, vegetation and everything that supports it. These observations seem staggeringly obvious - making it necessary to see harms to the biosphere as constituting harm to humanity as a whole, since we are collectively reliant on the biosphere for our existence.

Extending this appreciation of inter-reliance, it is undeniable that social networks are not only networks between people, but also between people and place, people and things, people and ecological processes. ${ }^{22}$ The physical world of nature and of artificial objects plays a significant role in all social relationships: place, material things, food, animals, microbes, soil fungus, air, fish, water, all co-exist ecologically and form an extended social network. 'Society' must therefore be understood as eco-society. ${ }^{23}$ On this basis, the concept of 'society' can be seen to include even the components of the soil - the nematodes, funghi, protozoa, and bacteria, as well as non-living nutrients, and even sand, clay and dirt: after all, the earth is circulated through our own bodies and is essential for our existence. The same is of course true of other elements identified by the ancients - wind, air, or atmosphere; fire or energy;

19. See, for instance, Irene Watson Aboriginal Peoples, Colonialism and International Law (Routledge, Abingdon, 2015); Ambelin Kwaymullina and Blaze Kwaymullina, 'Learning to Read the Signs: Law in an Indigenous Reality' (2010) 34 Journal of Australian Studies 195; Bradley Bryan, 'Property as Ontology: On Aboriginal and English Understandings of Ownership' (2000) 13 Canadian Journal of Law and Jurisprudence 3-31; Nin Tomas, 'Maori Concepts of Rangatiratanga, Kaitiakitanga, the Environment and Property Rights' in David Grinlinton and Prue Taylor (eds), Property Rights and Sustainability: The Evolution of Property Rights to Meet Ecological Challenges (Martinus Nijhoff, Leiden 2011).

20. Arturo Escobar, 'Thinking-Feeling with the Earth: Territorial Struggles and the Ontological Dimension of the Epistemologies of the South' (2016) 11(1) AIBR Revista de Antropologia Iberoamericana 11-32.

21. As explained in exquisite biochemical detail by Samantha Frost in Biocultural Creatures: Toward a New Theory of the Human (Duke University Press, Durham 2016); see also Scott Gilbert, Jan Sapp, and Alfred Tauber, 'A Symbiotic View of Life: We Have Never Been Individuals' 2012 Quarterly Review of Biology 87(4) 325-41; Marc de Leeuw and Sonja van Wichelen, Personhood in the Age of Biolegality: Brave New Law (Palgrave Macmillan, Cham, Switzerland 2020).

22. Donna Haraway, The Companion Species Manifesto: Dogs, People, and Significant Otherness (Prickly Paradigm Press, Chicago 2003); Bruno Latour, Reassembling the Social: An Introduction to Actor-Network Theory (Oxford University Press, Oxford 2005); Jane Bennett, Vibrant Matter: A Political Ecology of Things (Duke University Press, Durham 2010); Joanna Latimer and Mara Miele, 'Naturecultures? Science, Affect, and the Nonhuman' (2013) 13 Theory, Culture, and Society $5-31$.

23. Since law is intrinsically social, we should also say that law is eco-legal, that is, emergent from eco-sociality. 
and above all water. ${ }^{24}$ This is not to suggest either that this crude division of nature into four categories is exhaustive or that life is composed mechanically from elements. It is simply a heuristic for some of the essential conditions of human life. The human is first and foremost a physical and ecologically-connected being. Being human is not primarily about 'our' rationality, as so much commentary over the centuries has asserted (though that is not to say that rationality of a sort has nothing to do with being human). Both human cognition and embodied presence are reliant on material-semiotic engagements in an extended network formed by relationships. ${ }^{25}$ The term 'posthumanism' has been coined to describe approaches that start from the position that the human is a distributed and interconnected being rather than rational and self-contained. ${ }^{26}$

Western legal theory urgently needs the conceptual resources to encompass the coemergence of the human and the nonhuman. Legal theorists need such concepts for the purposes both of analysis of the past and present and in order to promote change. We also need them in order to promote an attitude of openness to Indigenous and other non-hegemonic knowledges, an attitude that involves decentring the ontoepistemic commitments of Eurocentric and colonial mainstream law and legal theory. As many have argued, the challenge is to reorient thought in such a way that human society is regarded as being a dimension of an ecological world which has ethical and ontological primacy. It is for this reason that I use the term eco-society to emphasize that 'human society' is part of the biosphere. Environmental injustice is eco-social injustice (or 'socio-ecological injustice, ${ }^{27}$ ) because it harms the conditions for human existence and it harms the extended socio-ecological networks that are shared by all living beings. Distributional inequities exist across eco-society understood in this sense, and not just in the imagined human sphere.

In order to connect the human to the nonhuman in the material world and in Western philosophical worldviews, it is important first to understand how their constructed onto-epistemic disconnection is manifested across existence and what its symptoms and causes are. In the following two sections of the article I focus on two critical ideas, each of which represents an assemblage of processes associated with European colonial interventionism and the extractive engagements with nature encouraged by Western political and philosophical thought. 'Fragmentation' and 'rift' are composite terms that place historical processes into a common framework with both ecological damage and the conceptual architecture of Western thought. As images or narratives, 'fragmentation' and 'rift' aggregate thoughts and practices that connect philosophy, social existence, and human-induced ecological change. The purpose of deploying these ideas here is primarily analytical and critical. Having sketched

24. David Macauley, Elemental Philosophy: Earth, Air, Fire and Water as Environmental Ideas (SUNY Press, Albany 2010).

25. Lambros Malafouris, How Things Shape the Mind (MIT Press, Cambridge, MA 2013); Lambros Malafouris, 'Metaplasticity and the Primacy of Material Engagement' (2015) 8(4) Time and Mind 351-71.

26. N Katherine Hayles, How We Became Posthuman: Virtual Bodies in Cybernetics, Literature, and Informatics (University of Chicago Press, Chicago 1999); Karen Barad, 'Posthumanist Performativity: Toward an Understanding of How Matter Comes to Matter' (2003) 28(3) Signs: Journal of Women in Culture and Society 801-31; Rosi Braidotti, The Posthuman (Cambridge, Polity 2013).

27. Donna Houston, 'Crisis is Where We Live: Environmental Justice for the Anthropocene' (2013) 10 Globalizations 439-50; Louis Kotzé, 'The Anthropocene, Earth System Vulnerability and Socio-Ecological Injustice in an Age of Human Rights' (2019) 10 Journal of Human Rights and the Environment 62-85. 
these ideas, I turn to the concept and practice of private property, which in its present form provides not only $a$, but arguably the archetypal legal technique of fragmentation and rift. The critique and analysis of property facilitated by the ideas of fragmentation and rift lays bare the need for a reconstructive approach that allows for a legal reconnection of life to its conditions of existence. Reimagining property as part of our habitat is a more relationally embedded possibility, and in the final section of the paper I sketch this as an alternative legal form.

\section{FRAGMENTATION}

'Fragmentation' is a term that can be used to describe a reduction and fracturing of the material conditions of life for both human beings and animals. In ecology, 'fragmentation' refers to destructive changes in the ecosystems that provide a habitat for nonhuman life - 'the division of habitat into smaller and more isolated fragments separated by a matrix of human-transformed land cover'. ${ }^{28}$ Habitat fragmentation is the result of land clearance for roads, agriculture, urban expansion, mines, and other industries. Increasingly, it is also the result of natural disasters that are worse as a result of human activities, as we have seen in the Australian bushfires of 2019-2020. These human-intensified disasters caused the destruction of millions of hectares of habitat and the deaths of potentially hundreds of millions of animals and can no longer be regarded, as they have so often been in the past, only as unfortunate natural occurrences. ${ }^{29}$ Habitat fragmentation is characterized by a loss of connectivity between areas of habitat, the shrinking sizes of the patches of land that constitute habitat, and a loss of habitat quality. It is also clearly associated with a reduction in biodiversity, as the resources needed to maintain a healthy level of redundancy in any ecosystem are reduced. Unsurprisingly, habitat fragmentation has also been associated with a loss of connection in animal social networks. ${ }^{30}$

Habitat fragmentation, loss, and degradation, though not always named as such, have also been a common feature of human history in the West: enclosures, clearances, colonization, urbanization, and gentrification have displaced large numbers of people and seriously downgraded their living conditions. ${ }^{31}$ These uprootings of people from places they had inhabited for generations (and in some cases millennia) were pursued in the name of 'improvement' of the land. ${ }^{32}$ Far from improving the

28. Nick Haddad et al., 'Habitat Fragmentation and its Lasting Impacts on Earth's Ecosystems' (2015) 1(2) Science Advances, DOI: 10.1126/sciadv.1500052. A vast literature on habitat fragmentation has accumulated since the 1960s: even the earliest literature warned about the effects of fragmentation on biodiversity.

29. Estimates have varied, from several hundred million to a billion. What is not in doubt is that the fires have destroyed a large amount of habitat and that some species will move closer to extinction as a result.

30. Sam C Banks et al., 'Sex and Sociality in a Disconnected World: A Review of the Impacts of Habitat Fragmentation on Animal Social Interaction' (2007) 85 Canadian Journal of Zoology 1065-79.

31. Karl Polanyi, The Great Transformation: The Political and Economic Origins of Our Time (first published 1944, Beacon Press, Boston 1957), in particular ch 3, 'Habitation versus Improvement'; Nicole Graham, Lawscape: Property, Environment, Law (Routledge, Abingdon 2011) 51-133.

32. Laura Brace, 'Husbanding the Earth and Hedging out the Poor' in AR Buck, John McLaren, and Nancy Wright (eds), Land and Freedom: Law, Property Rights, and the British Diaspora 
land, however, the result was often degradation of the soil and of biodiversity, as complex and integrated systems of agricultural management were replaced by monocultures and the use of artificial fertilizers. ${ }^{33}$ Whilst living conditions improved as a result of these changes for many people throughout the twentieth century, for many others improvement was too rapid and hence problematic, with excessive consumption replacing other forms of social connectedness. In developing nations, 'progress' has been much more patchy and is highly contingent upon the multiple ways in which value has been extracted from the poor by global capitalism. ${ }^{34}$ Precarious employment and material fragility across the world have in recent times been further exacerbated by the global financial crisis, austerity policies, and now a pandemic.

In addition to describing change in human and nonhuman conditions of subsistence, fragmentation is also a powerful description for many aspects of liberal and neoliberal human society. The term 'social fragmentation' is well established and such fragmentation has been studied for well over a century, though not always under that name. ${ }^{35}$ In the theoretical domain, fragmentation has been identified in the distinguishing or alienation of human individuals from an experience of community, in their inability to self-actualize, and in the separation of human society from nature. ${ }^{36}$ In applied scholarship, 'social fragmentation' is used to refer to a matrix of factors such as isolation, housing insecurity, and population instability in geographical areas. ${ }^{37}$ Social fragmentation is set up in this context as being the opposite to social cohesion, and is associated with a dissolution of social norms. ${ }^{38}$ Social fragmentation may or may not be associated with poverty and is also often studied for its influence on mental health. ${ }^{39}$ Meanwhile, non-geographical networks forged

(Ashgate, Dartmouth 2001); J Weaver, 'Concepts of Economic Improvement and the Social Construction of Property Rights: Highlights from the English-Speaking World' in John McLaren, AR Buck, and Nancy Wright (eds), Despotic Dominion: Property Rights in British Settler Societies (Cambridge University Press, Cambridge 2005); Brenna Bhandar Colonial Lives of Property: Law, Land, and Racial Regimes of Ownership (Duke University Press, Durham 2018), ch 3.

33. See, eg, Nicole Graham, Lawscape: Property, Environment, Law (Routledge, Abingdon 2011) 128-30. Graham reports that two methods used to 'improve' forests in colonial Australia were fire and ringbarking. See also Bruce Pascoe, Dark Eти (Magbala Books, Broome 2014). 34. Maria Mies, Patriarchy and Accumulation on a World Scale (Zed Books, New York 1986); David Harvey, The New Imperialism (Oxford University Press, Oxford 2001); Saskia Sassen, 'A Savage Sorting of Winners and Losers: Contemporary Versions of Primitive Accumulation' (2010) 7(1) Globalizations 23-50.

35. Émile Durkheim developed the concept of anomie to describe the disconnection of individuals from social norms. See, eg, É Durkheim, Suicide: A Study in Sociology (Free Press, New York 1951). Interestingly, he identified wealth - and wealthy communities - as risk factors for anomie: see pp. 213-14.

36. See, for instance, Axel Honneth's discussion of Georg Lukács' early writings in A Honneth, The Fragmented World of the Social: Essays in Social and Political Philosophy (SUNY Press, Albany 1995), in particular 51-3.

37. Social fragmentation or anomie indices have been used for some decades to measure such social fragmentation factors, particularly in urban neighborhoods. See G Davey Smith, E Whitley, D Dorling, and D Gunnell, 'Area Based Measures of Social and Economic Circumstances: Cause Specific Mortality Patterns Depend on the Choice of Index' (2001) 55 Journal of Epidemiology and Community Health 149-50.

38. See, eg, Émile Durkheim, Suicide: A Study in Sociology (Free Press, New York 1951) $207-15$.

39. See, for instance J Allardyce et al., 'Social Fragmentation, Deprivation and Urbanicity: Relation to First-Admission Rates for Psychoses' (2005) 187 British Journal of Psychiatry 
through the internet and social media complicate the study of cohesion and fragmentation, ${ }^{40}$ although such hybrid geographical-cyber spaces also provide the backdrop for new scholarship in both. ${ }^{41}$

Human society is fragmented in multiple, intersecting and sometimes indescribable ways, even for those of us who are relatively secure in a material sense. In addition to the fragmentation of the means of survival, established political systems have become notoriously fragmented and now appear - even to the relatively privileged to be increasingly unreliable. For colonized and vulnerable peoples, state political systems have always been dangerous and disconnected from their material lives, while the fractures of colonialism papered over by imposed solutions are constantly re-forming. ${ }^{42}$ Looking to an even more abstract layer of existence, it was frequently observed throughout the twentieth century that knowledge had become fragmented or compartmentalized: from the 'two cultures' of science and the arts noted by CP Snow in $1959,{ }^{43}$ scholarship has become divided into increasingly narrow (one might even say 'micro') specializations that do not communicate well with each other and are highly protective of the boundaries of their field. Critical and interdisciplinary interventions have destabilized some of the foundations of these epistemologically gated communities, but critique has also shown itself to be susceptible to a similar level of protectionism, with closed niches forming around father figures and specific disciplinary combinations. ${ }^{44}$ Despite these complexities, shifts, and fragmentations, disciplines still persist in a traditional form and obstacles to removing traditional (and newer) boundaries remain. Eurocentric knowledge thus broadly remains suspicious of outsiders and entrapped in its history.

Fragmentation is far from being the only consequence of intersecting historical processes of colonialism, industrialization, and individualization. Nor is such change always negative as far as every segment of human society is concerned: in many instances, the dissolution of old truths and structures is necessary for constructive transformations to occur. The appearance and perception of fragmentation can thus be highly situational and subjective. Ecological change is, however, overwhelmingly driving loss of habitat and hence of biodiversity on a once thriving planet. And while it might seem that the fragmentation of social existence is a different issue from the

401-6; James Fagg et al., 'Area Social Fragmentation, Social Support for Individuals and Psychosocial Health in Young Adults: Evidence from a National Survey in England' (2008) 66 Social Science and Medicine 242-54; Sigrid Mohnen et al., 'Neighbourhood Social Capital and Individual Health' (2011) 72 Social Science and Medicine 660-67; David Coburn, 'Income Inequality, Social Cohesion, and the Health Status of Populations: The Role of Neoliberalism' (2000) 51 Social Science and Medicine 135-46.

40. Leila Hedayatifar et al., 'US Social Fragmentation at Multiple Scales' (2019) 16(159) Journal of the Royal Society Interface.

41. Matt Reed and Daniel Keech, 'Gardening Cyberspace - Social Media and Hybrid Spaces in the Creation of Food Citizenship in the Bristol City-Region, UK' (2019) 44(7) Landscape Research 822-33.

42. For a recent discussion, see Stewart Motha, 'A "Dred Scott Moment" - But Not Only for the UK Supreme Court' (2019) <http://criticallegalthinking.com/2019/09/20/a-dred-scottmoment-but-not-only-for-the-u-k-supreme-court/?fbclid=IwAR0bkgGqV4FiF8P8UdEx8cCdtI Rh9tKLj_wRQ2Z0oXajg3P8xyzkRhHO4mA>.

43. CP Snow, 'Two Cultures' (1959) 130(3373) Science.

44. Anders Karlqvist, 'Going Beyond Disciplines' (1999) 32 Policy Sciences 379-83; Andrew Barry, Georgina Born and Gisa Weszkalnys, 'Logics of Interdisciplinarity' (2008) 37(1) Economy and Society 20-49. 
fragmentation of arctic sea ice, this perception of difference is itself a product of the separatist - or to use the Marxist term, alienated - epistemology of Western thinking. The matrix of factors that constitute the liberal-capitalist-rationalist worldview and that are responsible for these multiple layers of disconnection between the biophysical world and human society, and between body and mind, have been much discussed: ${ }^{45}$ these factors include individualism, the subject-object distinction, the ideology of mastery over nature, and the associated extractive mentality. Fragmentation is therefore a useful analytical frame for understanding certain types of historical change and in particular, as I will explain, especially those motivated by highly individualized and highly fungible practices of private property.

\section{RIFT}

The second idea that is useful in understanding the property-driven fractures in ecosociety is the notion of 'rift'. ${ }^{46}$ This is another concept that both creates and crosses the divide between physical and cultural processes. Until recently, Karl Marx was not much studied for his ecological thinking, pre-dating as he did, the major environmental movements of the twentieth century. Twenty years ago, however, John Bellamy Foster developed from Marx the notion of the 'metabolic rift', an idea that has now become popular in social-ecological thought. ${ }^{47}$ Early in Capital Marx speaks of labour as an 'eternal natural necessity which mediates the metabolism between man and nature, and therefore human life itself' ${ }^{48}$ The term 'metabolism' [Stoffwechsel in German] refers to the material exchange that takes place between human society and nature: human labour mediates that exchange for instance in the acts of collecting or growing food for consumption. Typically, labour for Marx involves the transformation of a raw material by the input of human energy. ${ }^{49}$ As an aside, I would point out that Marx's focus on human labour as the basis for value sidelines what Western thinking has rather belatedly discovered to be the agency of the soil, indeed the Earth's labour. ${ }^{50}$ The role of microbes, bacteria, and nutrients in growing things far

45. See, for instance, Val Plumwood, Feminism and the Mastery of Nature (Routledge, London 1993).

46. I am indebted to Nicole Graham for drawing my attention to the scholarship on metabolic rift. See in particular Nicole Graham, 'Dephysicalized Property and Shadow Lands' in Robyn Bartel and Jennifer Carter (eds), Handbook on Space, Place, and Law (Edward Elgar, Cheltenham UK 2021).

47. John Bellamy Foster, 'Marx's Theory of Metabolic Rift: Classical Foundations for Environmental Sociology' (1999) American Journal of Sociology 105(2) 366-405; see also John Bellamy Foster, Marx's Ecology: Materialism and Nature (Monthly Review Press, New York 2000); Nathan McClintock, 'Why Farm the City? Theorizing Urban Agriculture through a Lens of Metabolic Rift' (2010) 3(2) Cambridge Journal of Regions, Economy, and Society 191-207; Mindi Schneider and Philip McMichael, 'Deepening, and Repairing, the Metabolic Rift' (2010) 37(3) Journal of Peasant Studies 461-84.

48. Karl Marx, Capital: A Critique of Political Economy, Ben Fowkes (trans) (Penguin Books, London 1976) 133.

49. Ted Benton, 'Marxism and Natural Limits: An Ecological Critique and Reconstruction' (1989) 178 New Left Review 51-86, 66.

50. Teresa Brennan, 'Economy for the Earth: The Labour Theory of Value Without the Subject/ Object Distinction' (1997) 20 Ecological Economics 175-85. As Morgan Robertson explains, Marx in fact describes 'a unified metabolism between humans and material nature', but insists 
outweighs any human contribution as yet: humans can modify life, but not produce it, and to that extent everything productive is generated by the Earth.

Foster highlights several passages in Capital that form the basis for the notion of a rift in this metabolic exchange. Foster notes, for example, that Marx was drawing on the work of a German chemist, Liebig. ${ }^{51}$ For instance, at the end of Chapter 15 of Volume I, Marx argues that, because of urbanization,

Capitalist production ... disturbs the metabolic interaction between man and the earth, i.e. it prevents the return to the soil of its constituent elements consumed by man in the form of food and clothing; hence it hinders the operation of the eternal natural condition for the lasting fertility of the soil. ${ }^{52}$

Further, Marx says that 'all progress in capitalistic agriculture is a progress in the art, not only of robbing the worker, but of robbing the soil; all progress in increasing the fertility of the soil for a given time is a progress towards ruining the more longlasting sources of that fertility'. ${ }^{53}$ Under capitalist conditions, human-nature transactions are not an exchange, but rather an appropriation. 'Natural resources' transformed by labour into value for a human economy are not returned to nature, or at least not within a time frame whereby they can be naturally recycled and reused. This rupture in the processing of materials is the basis of human societies that are unsustainable. One result of this rupture was an agricultural demand for artificial phosphate fertilizers, a demand that was at one time addressed by the extensive devastation of Pacific Islands such as Nauru and Banaba through phosphate mining. ${ }^{54}$ As feminist ecophilosopher Val Plumwood argued, the costs of beautiful landscapes and forests close to the homes of the relatively privileged, as well as the costs of these comfortable private homes, are often outsourced to what she calls 'shadow places' 55 - those areas of the world too impoverished to insist on clean air, clean waterways and pollutionfree habitat.

that it is human labour that is the source of capitalist value; M Robertson, 'Measurement and Alienation: Making a World of Ecosystem Services' (2012) 37 Transactions of the Institute of British Geographers NS 386-401, 389. The extensive literature on ecosystem services that has flourished over the past three decades or so brings the contributions of nature into economic equations in an instrumental fashion - as services for humanity. See below.

51. See John Bellamy Foster, "Robbing the Earth of its Capital Stock" An introduction to George Waring's Agricultural Features of the Census of the United States for 1850' (1999) 12(3) Organization and Environment 293-7; George Waring, 'Agricultural Features of the Census of the United States for 1850' [1855] (1999) 12(3) Organization and Environment' 298-307.

52. Karl Marx, Capital: A Critique of Political Economy, Ben Fowkes (trans) (Penguin Books, London 1976) 637.

53. ibid 638 .

54. Katerina Teaiwa, 'Ruining Pacific Islands: Australia's Phosphate Imperialism' (2015) 46(3) Australian Historical Studies 374-91; see also Jimmy Skaggs, The Great Guano Rush: Entrepreneurs and American Overseas Expansion (St Martin's Press, New York 1994); Brett Clark and John Bellamy Foster, 'Ecological Imperialism and the Global Metabolic Rift: Unequal Exchange and the Guano/Nitrates Trade' (2009) 50(3) International Journal of Comparative Sociology 311-44.

55. Val Plumwood, 'Shadow Places and the Politics of Dwelling' (2008) 44 Australian Humanities Review 139-50; see also Nicole Graham 'Dephysicalized Property and Shadow Lands' in Robyn Bartel and Jennifer Carter (eds), Handbook on Space, Place, and Law (Edward Elgar, Cheltenham UK 2021). 
It is extremely interesting to think that Marx explicitly connected the exploitation of workers with the exploitation of the soil. It is good - reassuring even - from an academic perspective to have a term of art like 'metabolic rift' that identifies the interruption in the circulation of matter between human and nonhuman systems. However, it is dispiriting to note that the damaging effects of industrial agriculture were so well known in the nineteenth century that a prominent agricultural chemist from the United States, George Waring, could refer to "earth butchery and prodigality', ${ }^{56}$ stating that 'Man is but a tenant of the soil and he is guilty of a crime when he reduces its value for other tenants who are to come after him' ${ }^{57}$ The broad direction of metabolic rift has thus been known for well over a hundred and fifty years, but it is only in recent decades that the principles of sustainable and regenerative farming have seriously challenged the industrial mindset.

The problem of metabolic rift, however, remains. Underlining its extent is the following statement from a group of 800 scientists, published in The Australian newspaper in 1971:

It is very difficult to find in Australia one industrial process which, when traced through all its ramifications, is in balance with the supply of raw materials and with the ability of the environment to repair the damage which essential parts of most processes cause. Grazing and farming in much of our vast arid regions are reducing the capacity of the land to reproduce. ${ }^{58}$

And further, 'The web of life which nurtured man for a million years and on which man depends for his survival is falling to pieces'. There is now nothing at all remarkable about this statement or its message, though it is notable that it was published 50 years ago, when the rift observed by Liebig and theorized by Marx had already become critical. The Australian scientists were far from alone: there are many examples of scientists of the mid-twentieth century making similar observations. In the late 1960s, an informal thinktank, the Club of Rome, commissioned research into the 'predicament of mankind', resulting in a remarkable report, The Limits to Growth (1972). The authors argued that if exponential growth in 'population, industrialization, pollution, food production, and resource depletion' was not controlled then 'the most probable result will be a rather sudden and uncontrollable decline in both population and industrial capacity'. ${ }^{59}$

The rift inherent in industrial agriculture and the consequential damage to soil fertility is of course only one aspect of a great divide that modern humanity has established between human systems and earth systems. ${ }^{60}$ Rift is also a social and

56. George Waring, 'Agricultural Features of the Census of the United States for 1850' [1855] (1999) 12(3) Organization and Environment' 298-307, 306.

57. ibid. See generally John Bellamy Foster, "Robbing the Earth of its Capital Stock": An introduction to George Waring's Agricultural Features of the Census of the United States for 1850' (1999) 12(3) Organization and Environment 293-7.

58. Thank you to Rob Fowler, who mentioned this statement in the talk 'Sustainability and the Law', Hawke Centre, 10 September 2019.

59. Donella Meadows et al., The Limits to Growth: A Report for The Club of Rome's Project on the Predicament of Mankind (Universe Books, New York 1972) 23. See also Graham Turner, 'A Comparison of The Limits to Growth with 30 Years of Reality' (2008) 18 Global Environmental Change 397-411; Graham Turner, Is Global Collapse Imminent? (Melbourne Sustainable Society Institute, 2014).

60. Johan Rockström et al., 'Planetary Boundaries: Exploring the Safe Operating Space for Humanity' (2009) 14(2) Ecology and Society, article 32 (online). 
conceptual attitude and worldview based on the prevalent cultural narrative that divides human society from the natural environment and treats our human interests as greater than the interests of the planet. The onto-epistemological division of human from nonhuman is not universally held, but it is universally destructive because of the global reach of capitalism. In this sense, the idea of a rift between nature and culture is nothing new to scholarship: feminists and many others have discussed the dualisms that dominate thought concerning a separation between nature and society, and the gendered and racialized meanings that attach to each. ${ }^{61}$ Which is cause and which is effect - the rift in the circulation of matter or the more abstract rift in cultural worldview is indeterminate. ${ }^{62}$ Suffice it to say that these rifts are mutually reinforcing dimensions of a collective disposition and set of behaviours characterizing the preponderance of post-Enlightenment European and colonial interactions with the physical world.

The fragmentation and rift that were witnessed throughout the twentieth century were exacerbated by capitalism, but have also produced the conditions in which neoliberal capitalism has been able to accelerate eco-social degradation. Neoliberalism has removed the fetters from private accumulation, for instance through the privatization of public resources, by reduced government control, and by an emphasis on self-interest and aggressive individualism. Fragmentation has reduced individual and collective resilience to these trends as well as our ability to resist; while rift encourages a complete disconnection of human society from its own conditions of existence.

\section{THE ROLE OF PRIVATE PROPERTY}

The hoarding drive is boundless in its nature. ${ }^{63}$

Overweening ambition always exceeds the results obtained, great as they may be ... ${ }^{64}$

I have described the interconnected problems of social and environmental injustice as being characterized by widespread material and conceptual fragmentation and rift. This is a simplified overview of a complex terrain. My first objective has been to collect an apparently disparate set of issues under two broad narratives that bring the human and the nonhuman into a common analysis concerning the causes of ecocide. My second objective, outlined in this section, is to frame private property within these narratives. In its legal form private property is constituted by the conceptual fragmentation of the world and the rift between human and nonhuman. In turn, property facilitates eco-social fragmentation and rift as processes intrinsic to capitalist-colonial economies. Finally, in the next section, I offer some observations about how property might be reimagined in order to promote more constructive human-nonhuman engagements.

61. Carolyn Merchant, The Death of Nature: Women, Ecology, and the Scientific Revolution (Harper and Rowe, New York 1980); Val Plumwood, Feminism and the Mastery of Nature (Routledge, London 1993); Val Plumwood, Environmental Culture: The Ecological Crisis of Reason (Routledge, Abingdon 2002); Anna Grear, 'The Vulnerable Living Order: Human Rights and the Environment in a Critical and Philosophical Perspective' (2011) 2 Journal of Human Rights and the Environment 23-44.

62. But see the discussion in Mindi Schneider and Philip McMichael, 'Deepening, and Repairing, the Metabolic Rift' (2010) 37(3) Journal of Peasant Studies 461-84.

63. Karl Marx, Capital: A Critique of Political Economy, Ben Fowkes (trans) (Penguin Books, London 1976) 230.

64. Émile Durkheim, Suicide: A Study in Sociology (Free Press, New York 1951) 214. 
As noted in the previous section, the process of metabolic rift was attributed by Marx to capitalist agriculture that robbed both workers and nature. In the present day, and along the same lines, the cause of environmental destruction is frequently said to be the expectation that economies always deliver growth: ${ }^{65}$ this insistence on growth has been described as a ponzi scheme or a pyramid scheme. The centrality of growth as ideology means that while there is a limit to sustainable accumulation and a limit to planetary resources, there is no agreed political limit to economic growth. This growth mentality is clearly extremely destructive, but simply blaming economic growth begs the question of what it is that motivates and permits growth. While there are many factors that make up the social-ideological system that fixates on the view that growth is progress and drive the consequential destruction this causes when pursued unthinkingly, ${ }^{66}$ the most critical factor, and the focal point for this article, is private property. The capitalist system permits and even promotes unlimited accumulation of private property together with the personal power that property brings, allowing the costs of that accumulation to be outsourced via the extraction of value from both human and nonhuman spheres. Both the form and the practice of property are troubling because of the role of property both in producing huge social disparities and in facilitating environmental damage. Structurally and conceptually, private property has very few built-in restraints, meaning that - when pursued individually and collectively it feeds accelerating accumulation and an associated acceleration in ecocide.

Private property enshrines both the rift between human and nonhuman and the fragmentation that characterizes eco-society. The rift between human and nonhuman processes is co-extensive with private property as it is understood by Western law. In its modern legal form, private property is based on a division between owner and owned, subjects and objects. ${ }^{67}$ Humans are owners and property-holding subjects, while things - land, animals, consumer goods - are all objects of property. Regardless of any emotional, psychological or existential connection that a person may have to their 'objects of property', the division of subject from object, and the dominance of human owners over the nonhuman world, is basic to property's legal form. However, the subject and the object are categories constituted by law, philosophy, and a Euro-colonial narrative of fundamental 'human' difference from 'nature'. ${ }^{68}$ These categories have shifted over time: the history of slavery shows, for instance, that it took many centuries for the line between subject and object to be formally drawn to include all humans.

A system that divides the world into subjects and objects is intrinsically hierarchical, meaning that all of the things classified as objects are ontologically debased, can

65. See, for instance, the New Economics Foundation Report, Growth Isn't Possible (2010); Herman Daly, Beyond Growth: The Economics of Sustainable Development (Beacon Press, Boston, MA 1996); Herman Daly, 'A Further Critique of Growth Economics' (2013) 88 Ecological Economics 20-24; Donella Meadows et al., The Limits to Growth: A Report for The Club of Rome's Project on the Predicament of Mankind (Universe Books, New York 1972). 66. See JK Gibson-Graham, The End of Capitalism as We Knew It: A Feminist Critique of Political Economy (University of Minnesota Press, Minneapolis 2006).

67. James Penner, The Idea of Property in Law (Clarendon Press, Oxford 1997) 105-27; Margaret Davies 'Material Subjects and Vital Objects - Prefiguring Property and Rights for an Entangled World' (2016) 22(2) Australian Journal of Human Rights 37-60.

68. See, eg, Alain Pottage and Martha Mundy (eds), Law, Anthropology, and the Constitution of the Social: Making Persons and Things (Cambridge University Press, Cambridge 2004); Margaret Davies and Ngaire Naffine, Are Persons Property? Legal Debates About Property and Personality (Ashgate, London 2001). 
be treated as mere commodities for exchange, and treated as equals in economic exchanges. Land, for example, becomes abstract in real estate transactions so that it can participate fully in capitalist circulation. ${ }^{69}$ Aboriginal connections to country based on continuity between peoples and place are disrupted by the legal techniques of native title and translated into objectified formalities. ${ }^{70} \mathrm{~A}$ patch of land that supports ecological diversity can be exchanged via the medium of money for a specified number of plastic buckets. Ecologically valuable land can be reductively measured within the same system of value as can 'shares', 'followers', or 'likes' in the 'attention economy' ${ }^{71}$ Private property thus has a strong tendency to reduce things to a fungible form in which items can be exchanged for each other through what Marx called the universal commodity of money. ${ }^{72}$ All manner of things that really ought to be beyond monetary value are drawn into the process of exchange and have their distinct characteristics and wider value flattened: ${ }^{73}$ Marx called money 'the radical leveller', precisely because it 'does away with all distinctions'. This reduction is problematic for eco-social justice: in many instances the unique qualities of an item are levelled in the process of accumulation in the form of private property - and in a context where the fungibility of land is legally paramount, development driven by a profit outcome can all too easily reduce human and environmental safety to mere regulatory costs that need to be minimized. It seems perverse that resources that are critical to life on earth and to human well-being can be quantified according to the same measures as things that are entirely unnecessary and even destructive.

The economy constituted by the circulation within human society of money and privately owned resources is not the only economy that exists. ${ }^{74}$ It is however the

69. See, generally, Nicole Graham, Lawscape: Property, Environment, Law (Routledge, Abingdon 2011); Robyn Bartel and Nicole Graham, 'Property and Place Attachment: A Legal Geographical Analysis of Biodiversity Law Reform in New South Wales' (2016) 54(3) Geographical Research 267-84; Kenneth Vandevelde, 'The New Property of the Nineteenth Century: The Development of the Modern Concept of Property' (1980) 29(2) Buffalo Law Review 325-67.

70. Lee Godden, 'Legal Geography - Place, Time, Law and Method: The Spatial and Archival in Connection to Country' in Tayanah O'Donnell, Daniel Robinson, and Josephine Gillespie (eds), Legal Geography: Perspectives and Methods (Routledge, Abingdon 2020); see also Kathleen Birrell, Lee Godden, and Maureen Tehan, 'Climate Change and REDD+: Property as a Prism for Conceiving Indigenous Peoples' Engagement' (2012) 3(2) Journal of Human Rights and the Environment 196-216.

71. See eg, Alice Marwick, 'Instafame: Luxury Selfies in the Attention Economy' (2015) 27(1) Public Culture 137-60.

72. Also money: 'Just as in money every qualitative difference between commodities is extinguished, so too for its part, as a radical leveller, it extinguishes all distinctions.' Karl Marx Capital: A Critique of Political Economy, Ben Fowkes (trans) (Penguin Books, London 1976), 229.

73. Bartel et al., call such items 'notionally fungible commodities that are grown in nonfungible conditions', see R Bartel et al., 'Legal Geography: An Australian Perspective' (2013) 51(4) Geographical Research 339. Margaret Radin's provocative title also makes the point: 'What, If Anything, Is Wrong with Baby Selling?' (1995) 26(2) Pacific Law Review 135-46. See also M Radin, 'Property and Personhood' (1982) 34 Stanford Law Review 957-1015; Kenneth Vandevelde, 'The New Property of the Nineteenth Century: The Development of the Modern Concept of Property' (1980) 29(2) Buffalo Law Review 325-67.

74. JK Gibson-Graham, The End of Capitalism (As We Knew It): A Feminist Critique of Political Economy (2nd edn, University of Minnesota Press, Minneapolis 2006). 
dominant one and has the power to consume other economies and alternative forms of property. Scholarly and activist efforts to revitalize and strengthen the commons ${ }^{75}$ activate these alternatives but are also a symptom of the loss of the significant value once accorded to the public interest, public space, and publicly-owned goods. ${ }^{76}$ (This is not to suggest that political economy is moving inevitably in the direction of destruction: many practical resistances and more constructive narratives also exist.) A critical feature of the economic, material, and ontological rift between human society and the rest of the biosphere is that the ecosystem in itself has no value in the economic systems of the capitalist West. It is only seen to be of value for the raw materials it can provide and is otherwise fully external to society and the dominant economy. This logic means that one of the most legible remedies for environmental destruction has been to monetize environmental goods through mechanisms such as carbon trading or ecosystem services accounting. ${ }^{77}$ These approaches commodify nature and attach a monetary value to it so that it can be exchanged in the market, just like other goods. Such mechanisms and approaches have the merit of making 'the environment' visible to the most powerful system of value accounting that exists for global capitalism, but remain ontologically problematic precisely because they work via the levelling process associated with money. ${ }^{78}$ As Nicole Graham has explored in detail, ${ }^{79}$ the commodification of nature dephysicalizes it and alienates human beings further from the natural material connections we are formed from.

Fragmentation is also intrinsic to property, and to property relations governing land in particular. Some forms of fragmentation are only made possible by legal doctrine. For instance, different legal persons can have property rights in the one piece of land - rights such as ownership, lease, easement, or mortgage. Fragmented property interests such as these are reasonably well defined in law but can become distorted by market forces: in the subprime mortgage crisis, for instance, mortgages were bundled up, sold on, and disguised in various ways. ${ }^{80}$ Private property therefore is fragmentary

75. Jane Holder and Tatiana Flessas, 'Emerging Commons' (2008) 17 Social and Legal Studies 299-310; Alison Young, 'Cities in the City: Street Art, Enchantment, and the Urban Commons' (2014) 26(2) Law and Literature 145-61; Matthew Turner, 'Political Ecology III: The Commons and Commoning' (2017) 41(6) Progress in Human Geography 791-802.

76. Antonia Layard, for instance, has written about the 'swathes' of property privatizations in England, and argued that they are 'a clear example of accumulation by dispossession', as analysed by David Harvey. See Layard, 'Public Space: Property, Lines, Interruptions' (2016) 2 Journal of Law, Property, and Society 1-47, 15; see also David Harvey The New Imperialism (Oxford University Press, Oxford 2001); Saskia Sassen, 'A Savage Sorting of Winners and Losers: Contemporary Versions of Primitive Accumulation' (2010) 7(1) Globalizations 23-50. 77. Robert Costanza et al., 'Twenty Years of Ecosystem Services: How Far Have We Come and How Far Do We Still Need to Go?' (2017) 28 Ecosystem Services 1-16.

78. Morgan Robertson, 'Measurement and Alienation: Making a World of Ecosystem Services' (2012) 37 Transactions of the Institute of British Geographers NS 386-401; Matthias Schröter et al., 'Ecosystem Services as a Contested Concept: A Synthesis of Critique and Counter-Arguments' (2014) 7(6) Conservation Letters 514-23.

79. Nicole Graham, Lawscape: Property, Environment, Law (Routledge, Abingdon 2011); 'Dephysicalized Property and Shadow Lands' in Robyn Bartel and Jennifer Carter (eds), Handbook on Space, Place, and Law (Edward Elgar, Cheltenham UK 2021).

80. Adam Ashcraft and Til Schuermann, Understanding the Securitization of Subprime Mortgage Credit (Now Publishers, Boston 2008); Amiyatosh Purdanandam, 'Originate-to-Distribute Model and the Subprime Mortgage Crisis’ (2011) 24 Journal of Financial Studies 1881-915. 
in form but is also obviously responsible for producing eco-social fragmentation of the types I have already spoken of. ${ }^{81}$ Ecosystem destruction and fragmentation are the results of land clearances made in the name of improvement and economic advancement, and the many forms of human social fragmentation can at least partly be attributed to multifaceted inequality caused by unlimited accumulation and by successive removals of resources from public and common ownership.

Private property carves up conceptual and physical space and creates eco-social vulnerability because it consists of a right to exclude the world at large. Because private property is a right to exclude, it is a form of private power exercised by an owner over the rest of humanity and over nature. As Van der Walt pointed out '.. property law is not exclusively or even primarily about owners and holders of rights, but about ... those who are required to respect property and who are owned as or through property' ${ }^{82}$ Property law creates a system that necessarily gives private owners power over non-owners and in fact that is its main point, which is operationalized through property's legal form. And because the objects of property, whether land, artworks, or plastic buckets, are reducible to monetary value, there is no limit to what a single person can own. The accumulation of property is never just an accumulation of money in the bank or a portfolio of shares and investments - such property amounts to an accumulation of power over others. This is a very old point, ${ }^{83}$ but one that is often still unrecognized in neoliberal thinking, which insists on formal notions of equality even while promoting aggressive individualism. Private property may have emerged out of feudalism, but the inequalities it generates amount to a neo-feudalism based on intense concentrations of power and the ability of those who wield that power to extract service from people in endlessly creative ways. ${ }^{84}$

Commodification and fungibility are offset to some degree, however, by the interest that the public or community has in certain resources: not all property is privately owned and not every aspect of privately owned property is exclusively under the power of its owner. The opportunities for unlimited accumulation and the transfer of the costs of accumulation can be reined in by effective government regulation. In many instances, externalities produced by an unregulated market are in fact controlled in this way. Employment laws protect workers from the worst exploitation, building regulation prevents the most dangerous construction, while the role of environmental law is to put a brake on the worst forms of environmental destruction. However, government regulation has many weaknesses, partly because of its instrumental focus $^{85}$ - it often represents a compromise, is ineffectively applied, can be watered down or abandoned, is frequently under-resourced, and often prioritizes short-term goals. Moreover, just as significantly, governments are now more susceptible than

81. See, eg, Peter Burdon 'What is Good Land Use? From Rights to Relationship' (2010) 34 Melbourne University Law Review 708-55.

82. AJ Van der Walt, 'Property and Marginality' 81-105 in Gregory Alexander and Eduardo Penalver, Property and Community (Oxford University Press, Oxford 2010).

83. See Morris Cohen, 'Property and Sovereignty' (1928) 13 Cornell Law Review 8-30; Roger Cotterrell, 'Power, Property and the Law of Trusts: A Partial Agenda for Critical Legal Scholarship' in Peter Fitzpatrick and Alan Hunt (eds), Critical Legal Studies (Blackwell, Oxford 1987).

84. See, eg, Peter Drahos and John Braithwaite, Information Feudalism (Earthscan, London 2002).

85. See, eg, Christine Parker and Fiona Haines, 'An Ecological Approach to Regulatory Studies?' (2018) 45(1) Journal of Law and Society 136-55. 
ever to corporate power. The neoliberal state is hardly a reliable guarantor of adequate regulatory protection.

In sum, private property in its modern Western and imperial form is constituted by a rift between individualized human subjects and their objectified world and by the fragmentation, or potential fragmentation, of interests in this objectifiable world. Private property underpins and facilitates high-flow capitalism, which relies on the massive circulation of fungible commodities and on the 'accumulation by dispossession' 86 of insufficiently protected resources, including the ecosystems, broadly understood, that support human and nonhuman life. Private property promotes, but is also is driven to its extremes by, such dynamics. Transforming property rests on a number of strategies across the continuum of promoting alternative practices and imaginings of private property itself, through to efforts to strengthen the commons and the public domain. ${ }^{87}$ Such possibilities are forged around reconnecting the relationships broken by private property. In the next section, I turn to one narrative that can help guide these strategies.

\section{HABITAT $^{88}$}

At its simplest, the remedy for all forms of fragmentation and rift is relational and integrated thinking of the type that feminism and ecological philosophy have been promoting for some decades and that Indigenous philosophies have understood for millennia. Such thinking does not mean a return to pre-industrial or to communal forms of life, even though extractive industrial capitalism has so widely been identified as the critical driver of a disintegrating world. History is cumulative and there can never be any return, even where such a thing might at first glance appear desirable. Rather, the imperative is for new eco-social formations that are balanced, fair, and sustainable in the long term.

Relational thinking proceeds on the understanding that people and things do not pre-exist their relationships but are formed in adaptive connections with their surroundings. ${ }^{89}$ Any 'fixed' properties that a person, a class of people, or a thing

86. David Harvey, The New Imperialism (Oxford University Press, Oxford 2001); Saskia Sassen, 'A Savage Sorting of Winners and Losers: Contemporary Versions of Primitive Accumulation' (2010) 7(1) Globalizations 23-50.

87. Davina Cooper, 'Opening Up Ownership: Community, Belonging, Belongings, and the Productive Life of Property' (2007) 32(3) Law and Social Inquiry 625-64; Nicholas Blomley 'Performing Property: Making the World' 26(1) Canadian Journal of Law and Jurisprudence 23-48; Sarah Keenan, Subversive Property: Law and the Production of Spaces of Belonging (Routledge, Abingdon 2015); Antonia Layard, 'Public Space: Property, Lines, Interruptions' (2016) 2 Journal of Law, Property, and Society 1-47; Cristy Clark and John Page, 'Of Protest, the Commons, and Customary Public Rights: An Ancient Tale of the Lawful Forest' (2019) 42(1) UNSW Law Journal 26-59.

88. See, further, Margaret Davies, Lee Godden and Nicole Graham, 'Situating Property Within Habitat: Reintegrating Place, People, and the Law' (2021) 6 Journal of Law, Property, and Society, article 1 (online).

89. Jennifer Nedelsky, 'Law, Boundaries, and the Bounded Self' (1990) 30 Representations 162-89; Jennifer Nedelsky, Law's Relations: A Relational Theory of Self, Autonomy, and Law (Oxford University Press, Oxford 2011); Karen Barad, Meeting the Universe Halfway: Quantum Physics and the Entanglement of Matter and Meaning (Duke University Press, Durham 2007); Ian Hodder, Entangled: An Archaeology of the Relationships Between Humans and Things (Wiley-Blackwell, Chichester 2012); Will Adams, 'The Primacy of Interrelating: Practicing Ecological Psychology with Buber, Levinas, and Merleau-Ponty' 
appears to have are in reality the product of complex and dynamic relationships that emerge and are sedimented over different time scales - from eons to moments.

Feminist thought addresses the politics of being human and, for it, relationality has mainly been theorized as concerning the relations that constitute an intra-human sphere and the ways in which such relationalities are disrupted and fractured by a male-centred consciousness. Ecofeminism combines this political consciousness with ecological thinking ${ }^{90}$ which is relational in that it perceives that in biology "everything in the environment is connected to everything else'.$^{91}$ Indigenous peoples across the globe have understood these connections for far longer: Mary Graham is an Aboriginal philosopher of the Kombu-merri people. She says: 'The two most important kinds of relationship in life are, firstly, those between land and people and, secondly, those among people themselves, the second always being contingent upon the first. The land, and how we treat it, is what determines our human-ness' ${ }^{92}$ The attachment of people to place has received some legislative recognition and support in Aotearoa New Zealand, where the personhood and rights of several natural entities have been recognized - a national park (Te Urewera); a river (Whanganui); and a mountain (Mount Taranaki). ${ }^{93}$ These reforms are specifically located, and do not necessarily suggest that nature as a whole possesses rights or personality. Nevertheless, such legal reforms do illustrate the possibilities for a more holistic and relational view of eco-society and an approach that brings human and nonhuman into a single frame of reference. ${ }^{94}$ They therefore represent one method of addressing historical and eco-social fragmentation and rift for particular human-nonhuman communities.

There have been many efforts to reimagine private property in a more relational way. Many property thinkers have emphasized that because it is socially constituted, property therefore requires obligations as well as rights. ${ }^{95}$ After all, the only reason anybody owns property is because the law creates and protects it. This fact in itself

(2007) 38 Journal of Phenomenological Psychology 24-61; Anna Grear, 'The Vulnerable Living Order: Human Rights and the Environment in a Critical and Philosophical Perspective' (2011) 2(1) Journal of Human Rights and the Environment 23-44.

90. See, eg, Val Plumwood, Feminism and the Mastery of Nature (Routledge, London 1993); see also Karen Warren, ‘The Power and the Promise of Ecological Feminism' (1990) 12(2) Environmental Ethics 121-46; Vandana Shiva, Staying Alive: Women, Ecology and Feminism (Zed Books, London 1989).

91. Barry Commoner, The Closing Circle: Nature, Man, and Technology (Bantam Books, New York 1972) 11. See also Arne Naess, 'The Shallow and the Deep, Long-Range Ecology Movement: A Summary' (1973) 16 Inquiry 95-100; Simone Bignall, Steve Hemming, and Daryl Rigney, 'Three Ecosophies for the Anthropocene: Environmental Governance, Continental Posthumanism, and Indigenous Expressivism' (2016) 10(4) Deleuze Studies 455-78.

92. Mary Graham, 'Some Thoughts About the Philosophical Underpinnings of Aboriginal Worldviews' (2008) 45 Australian Humanities Review 181-94, 181.

93. Andrew Geddis and Jacinta Ruru, 'Places as Persons: Creating a New Framework for Maori-Crown Relations' in Jason Varuhas (ed), The Frontiers of Public Law (Hart Publishing, Oxford 2020); Katherine Sanders, “"Beyond Human Ownership": Property, Power, and Legal Personality for Nature in Aotearoa New Zealand' (2018) 30 Journal of Environmental Law 207-34.

94. See, generally, Cristy Clark, Nia Emmanouil, John Page, and Alessandro Pelizzon, 'Can You Hear the Rivers Sing? Legal Personhood, Ontology, and the Nitty-Gritty of Governance' (2018) 45 Ecology Law Quarterly 787-844.

95. Eric Freyfogle, 'Context and Accommodation in Modern Property Law' (1989) 41 Stanford Law Review 1529-56; Gregory Alexander, 'Ownership and Obligations: The Human Flourishing Theory of Property' (2013) 43(2) Hong Kong Law Journal 451-62; Joseph William Singer, Entitlement: The Paradoxes of Property (Yale University Press, New Haven 2000). 
should be sufficient to generate extensive reciprocal obligations to society and to the public at large. Many have also argued that land ownership ought to bring with it the obligation to act as a steward or custodian so that it is passed to the next owner in an ecologically improved state. ${ }^{96}$ The challenge for law is to integrate these ideas of responsibility into legal ownership and in particular into legal ownership of land. Is it possible to connect and to deepen the legal obligations of owners so that property is regarded as bringing a commitment to both human and nonhuman life? How can property be thought ecologically to encompass intersecting planes of human and nonhuman sociality? ${ }^{97}$ Is it possible to recreate real property so that it is co-extensive with the conditions for life, that is, with human and nonhuman habitat?

Such a recreation would necessarily involve recalibrating what it means to be a person under the law: rather than a bounded individual with specific rights, we would need to be legally visible as ecologically connected beings who subsist in constitutive connection with place, land, and nonhuman beings. In ongoing research, Lee Godden, Nicole Graham, and I have been working on the notion of 'habitat' as a critical point of material connection between the human and the nonhuman, and a conceptual bridge across the legal divide that presently separates life forms. ${ }^{98}$ As Samantha Frost says:

[W] hen an organism develops and lives its life, it not only assimilates, appropriates, and engages with its habitat but also is modified through that assimilation, appropriation, and engagement. ... We could say then, that a developing and growing organism constitutes and reconstitutes itself, composes and recomposes itself, through its responses to features of its habitat. ${ }^{99}$

In the scientific register, the idea of habitat primarily speaks to the biological needs of organisms. ${ }^{100}$ Habitat is thus ordinarily associated with the unique characteristics of particular places and the biodiversity that brings resilience and adaptability to life. Given organism adaptability, habitat is not necessarily provided only by undamaged natural areas, but can refer to any place where life is possible. However, not only are organisms responsive to habitat, they alter it - adaptation is not

96. James Karp, ‘A Private Property Duty of Stewardship: Changing Our Land Ethic' (1993) 23 Environmental Law 735-62; William Lucy and Catherine Mitchell, 'Replacing Private Property: The Case for Stewardship' (1996) 55 Cambridge Law Journal 566-600; see, generally, Emily Barritt, 'Conceptualising Stewardship in Environmental Law' (2014) 26 Environmental Law Journal 1-26.

97. This is not a new question at all: see Margherita Pieraccini, 'Property Pluralism and the Partial Reflexivity of Conservation Law: The Case of Upland Commons in England and Wales' (2012) 3(2) Journal of Human Rights and the Environment 273-87; Anna Grear, 'Human Rights, Property, and the Search for "Worlds Other"' (2012) 3(2) Journal of Human Rights and the Environment 173-95.

98. The literature on habitat is vast. For a discussion of the use of the term see Peter Alagona, 'What is Habitat?' (2011) 16 Environmental History 433-8; see also Linnea Hall, Paul Krausman, and Michael Morrison, 'The Habitat Concept and a Plea for Standard Terminology' (1997) 25(1) Wildlife Society Bulletin 173-82. For a more extensive discussion of habitat and property see Margaret Davies, Lee Godden and Nicole Graham, 'Situating Property Within Habitat: Reintegrating Place, People, and the Law' (2021) 6 Journal of Law, Property, and Society, article 1 (online). 99. Samantha Frost, Biocultural Creatures: Toward a New Theory of the Human (Duke University Press, Durham 2016) 122.

100. A scientific discussion is found in Peter Alagona, 'What is Habitat?' (2011) 16 Environmental History 433-8, 438. 
unidirectional, but rather multifaceted and distributed. Clearly, habitat can be evaluated according to both quantitative and qualitative factors. In social-ecological thought the idea of habitat extends across the multiple intersecting ecologies of physical and social well-being. As Deleuze and Guattari put it, '[e]very territory, every habitat, joins up not only its spatiotemporal but its qualitative planes or sections'. ${ }^{101}$ If eco-social habitat were to function as a guiding material practice of property, therefore, it has the potential to promote a more inclusive, more relational, more situated, and less hierarchical view of property, which would, by definition, make the externalization of costs in the process of aggregating property impossible. I will explain these points in more detail shortly, after a brief detour via a previous attempt to conceptualize property as habitat.

\subsection{Habitat as a metaphor for property: Reich's view}

The connection of property with habitat was made nearly thirty years ago by the well-known US property theorist, Charles Reich. Reich was famous in property circles for his argument that all forms of valuable government distributions - jobs, welfare, licences, and contracts - should be recognized as private property. ${ }^{102}$ In a highly individualistic society, his concern was to bolster individual resilience against wealthy interests and against political intrusions into people's economic well-being. Reich also argued that property is like animal habitat:

Like an animal's habitat, property represents the individual's means of survival. It is attached to the individual by a biological bond. Indeed, it is part of the definition of the individual. We would not define a fish in such a way as to exclude the water in which it swims, nor would we define a bird without its nesting site, nor an otter without its food supply. Life does not exist in artificial isolation. ${ }^{103}$

Animals, in other words, need habitat to survive and humans need property. Habitat is the condition of survival for all life - without habitat, there is no life: ${ }^{104}$ if you take the fish out of water, in a short while you just get a dead fish. ${ }^{105}$ Ultimately, if you remove or fragment too much human habitat, we will also die. But Reich switches too quickly from animal habitat to human property without considering how property might need to change in order to be habitat. Property in its current form is not the same for humans as habitat is for animals (including humans): in fact, the idea of property

101. Gilles Deleuze and Felix Guattari, What is Philosophy? (Verso, London 1994)185, as discussed by Lorraine Code, Ecological Thinking: The Politics of Epistemic Location (Oxford University Press, Oxford 2006) 25-7.

102. Charles Reich, 'The New Property' (1964) 73 Yale Law Journal 733-87. Reich's analysis is discussed further in Margaret Davies, Lee Godden and Nicole Graham, 'Situating Property Within Habitat: Reintegrating Place, People, and the Law' (2021) 6 Journal of Law, Property, and Society, article 1 (online).

103. Charles Reich, 'Beyond the New Property: An Ecological View of Due Process' (1990) 56 Brooklyn Law Review 731-45, 737.

104. The habitat-organism relation is examined in minute detail by Samantha Frost in Biocultural Creatures: Toward a New Theory of the Human (Duke University Press, Durham 2016). 105. You also get dead fish if you allow the oxygen to be removed from the water, as Australia found a few years ago, with millions of native fish dying in one of our river systems. See Investigation of the Causes of Mass Fish Kills in the Menindee Region NSW Over the Summer of 20182019 (Australian Academy of Science, February 2019). 
that allows unlimited accumulation and the externalization of harms, as I have already argued, is the source of enormous problems and has resulted in the degradation of both human and nonhuman habitat. The liberal solution to inequality among humans as promoted by Reich is to improve individual security by widening the definition of property but not changing its form. ${ }^{106}$ In a highly commercialized world, private property does supply habitat in the short term for many, and the very wealthy may be able to buy their means of survival for quite a long time - but this approach will not help eco-society at large.

\subsection{Towards property as habitat}

Reich's solution was limited by his liberalism. But property needs to be aligned with, or secondary to, human and nonhuman habitat - in more imaginative and relevant ways. Several particular directions for further development are worth mentioning. ${ }^{107}$

It is vital that the distinctive characteristics of particular places should be understood in order to maximize the chances of protecting biodiversity and ecosystems. As Robyn Bartel and Nicole Graham have suggested, developing consciousness of person-place attachment, and finding ways to strengthen its protection in law, will allow a more localized understanding of property to emerge. ${ }^{108}$ Habitat is local but it is also connected to global eco-social systems. An idea of property that is embedded in localities and tied to protecting the ecological integrity of places also needs to be practised ecologically, which means looking beyond immediate locations and ensuring that costs are not externalized to distant 'shadow places'. ${ }^{109}$ Geographical inequalities in the existence of habitat also need to be identified and eliminated by pairing rights to draw on the resources of a particular location with responsibilities to sustain it. ${ }^{110}$

A relational understanding of property would therefore also involve flattening the hierarchies between owner and owned and those between owner and non-owner, as well as comprehending all as components of a networked agency. A more equal

106. See, generally, Charles Reich, 'The New Property' (1964) 73 Yale Law Journal 733-87; Charles Reich, 'Beyond the New Property: An Ecological View of Due Process' (1990) 56 Brooklyn Law Review 731-45, 735.

107. Some of these are reflected in the UN-Habitat Agenda: <https://open.unhabitat.org/>.

108. See generally Robyn Bartel and Nicole Graham, 'Property and Place Attachment: A Legal Geographical Analysis of Biodiversity Law Reform in New South Wales' (2016) 54(3) Geographical Research 267-84. See also Sarah Keenan, Subversive Property: Law and the Productive Spaces of Belonging (Routledge, Abingdon 2015). The Yarra River Protection (Wilip-gin Birrarung murron) Act 2017 (Victoria, Australia) defines particular areas as Yarra River land that are exclusive of private property. It is possible, however, to imagine such a regime that did extend to private property, as it provides a framework for conceptualizing the whole river; similarly the Te Awa Tupua (Whanganui River Claims Settlement) Act 2017 (New Zealand) is a co-management agreement and involves collective ownership, but could potentially be combined with private property.

109. Val Plumwood, 'Shadow Places and the Politics of Dwelling' (2008) 44 Australian Humanities Review 139-50; see also Nicole Graham, 'Dephysicalized Property and Shadow Lands' in Robyn Bartel and Jennifer Carter (eds), Handbook on Space, Place, and Law (Edward Elgar, Cheltenham UK 2021).

110. Val Plumwood, 'Shadow Places and the Politics of Dwelling' (2008) 44 Australian Humanities Review 139-50; see also Nicole Graham 'Dephysicalized Property and Shadow Lands' in Robyn Bartel and Jennifer Carter (eds), Handbook on Space, Place, and Law (Edward Elgar, Cheltenham UK 2021). 
relationship between owner and owned involves recognition that the subject-object positions in any relationship are mobile and emergent, rather than fixed. ${ }^{111}$ The 'owner' is addressed or interpellated by the object of property, which also expresses itself as an agent, ${ }^{112}$ even as the owner has certain interests in relation to it. The human legal subject who is truly understood as emergent from relationships is one where belonging is understood as the relationship of a part to a whole, as Davina Cooper has argued. ${ }^{113}$ An owner who belongs in this way can never rise above their plural ecological connections, though some differentiation, some 'relational autonomy' is essential and desirable. The idea that human beings care for resources that they 'own' is not at all foreign to even the most individualistic thinking, whether that thing is a pet, an heirloom, a home, a garden, or a farm. The step away from individualism however can only occur when such care is understood as owed across all of the different registers of social-ecological becoming. A more equal relationship between owners and non-owners can be promoted in many ways: finding ways to limit destructive forms of accumulation, improving distributions of property, and rigorously protecting and strengthening the commons and public space. Where the community or public has an interest in a resource, the positions of subject and object are necessarily more fluid, even interchangeable: each person in a group with common rights over a thing is answerable both to the resource and to the others who use it. More radical change is also warranted that would acknowledge that property is a gift from the commons to the individual, not an entitlement of those who have happened to secure whatever 'object' of property is in question.

Thinking of property within the framework of habitat is therefore about making property more inclusive, rather than defining it primarily through exclusive rights. ${ }^{114}$ Habitat is biodiverse, not monocultural. Engaging habitat as a conceptual benchmark for property might mean promoting multiple uses (including nonhuman uses) that can co-exist with individual human rights: there are examples of this already outside urban areas with the rights of way that exist in Britain, the co-existence of native title with pastoral leases in Australia, and communal forest rights in Sweden. From the perspective of the private owner, the co-existence of public and private rights is often experienced as a loss of their own amenity and property. A more integrated narrative of place, ecology, and human-nonhuman communities would in time render this idea of a 'loss' less coherent. Where non-private elements are regarded as inherent to property, and where real property is securely attached to place and the continuance of nonhuman life, the power associated with the property is necessarily less concentrated and less hierarchical.

111. Margaret Davies, 'Material Subjects and Vital Objects: Prefiguring Property and Rights for an Entangled World' (2016) 22(2) Australian Journal of Human Rights 37-60.

112. On agency of the object of property see Margherita Pieraccini, 'Property Pluralism and the Partial Reflexivity of Conservation Law: The Case of Upland Commons in England and Wales' (2012) 3(2) Journal of Human Rights and the Environment 273-87; Margaret Davies, 'Can Property be Justified in an Entangled World?' (2020) 17(7) Globalizations 1104-17.

113. Davina Cooper, 'Opening Up Ownership: Community, Belonging, Belongings, and the Productive Life of Property' (2007) 32(3) Law and Social Inquiry 625-64; see also Sarah Keenan, Subversive Property: Law and the Productive Spaces of Belonging (Routledge, Abingdon 2015), especially ch 4.

114. Anna Grear, 'Human Rights, Property, and the Search for "Worlds Other" (2012) 3(2) Journal of Human Rights and the Environment 173-95. 


\section{CONCLUSION}

Calls to reform property have existed for decades and have intensified in recent years. Urgency about the issue arises from several ongoing processes: environmental destruction, continuing colonialism and imperialism, and increasing inequality. Calls for radical reform are undoubtedly also a reaction to the extremes of neoliberalism that have characterized the last few decades of economic policy and the consequential intensification of property-led destruction. A long historical view illustrates that property as a practice and an idea does change, very substantially, despite its apparent resistance to change in the present legal system. Changes to the form of property coincide with and are co-implicated in changes to landscapes, to political systems, to geopolitical and personal distributions of power, and to the status of human individuals.

The problem posed by ecocide is that change to conceptions of property is needed more or less immediately, not over the next few centuries, and is needed on several fronts simultaneously. In this article, I have endeavoured to re-frame certain theoretical aspects of the debate about property reform, so that both the negative impacts and the constructive reform of property are seen as eco-social interventions. 